\title{
Creating Dialogue between Science and Religion
}

\section{Salar Ziro Abdullah}

Salar.ziro@outlook.com

\begin{abstract}
Searching for common ground in philosophy, science and theology, it seems to us that it would be reasonable to maintain the position of realistic pragmatism that Charles Sanders Peirce had called pragmaticism. In the pragmaticist manner, we typify the knowledge and select the types of knowledge that might be useful for understanding the problems that are of interest to us. We pose a question of how it would be possible to obtain practically useful information about reality, first from the perspective of natural sciences, and then from that of theology; that is, to diversify the ways of knowledge and just maybe, to move toward a productive dialogue between science and religion. Searching for common ground in philosophy, science and theology, it seems to us that it would be reasonable to maintain the position of realistic pragmatism that Charles Sanders Peirce had called pragmaticism. In the pragmaticist manner, we typify the knowledge and select the types of knowledge that might be useful for understanding the problems that are of interest to us. We pose a question of how it would be possible to obtain practically useful information about reality, first from the perspective of natural sciences, and then from that of theology; that is, to diversify the ways of knowledge and just maybe, to move toward a productive dialogue between science and religion.
\end{abstract}

Keywords—Religion, Science, Dialogue, Islam.

\section{INTRODUCTION}

That there is such a thing as 'religion' in the world few would deny. Everyone today, at least in the West, seems to know what religion is and, just as important, everyone seems to know what religion is not. A familiar account is that religion can be best explained as a certain set of beliefs, rules, and practices for living. It is thought to be belief in a transce1ndent reality, one that is not part of this material world, one that is holy, or sacred, and makes certain things in this world holy or sacred. It consists of performing rituals at times, and, of course, it is often belief in a higher power, a God or gods. Additionally, it is thought to be a set of beliefs that explain and interpret life and, by implication, the nature of ultimate reality. To believe in this type of transcendent reality and to perform the prescribed behaviors or rituals is to be religious, so the typical account goes. We in the West use the term, religion, freely and assume everyone knows what we are talking about. We refer to Christianity, Judaism, Islam, and Buddhism, for example, as religions and the adherents of these as those who are religious. There are the faithful, those who follow their religion consciously and consistently, there are those who are somewhat religious, and, of course, there are those who have no religion at all. The common understanding seems to be that there is religion and non-religion, religious people and non-religious people, and there are religious views and there are nonreligious views.

Creation refers in part to the genesis of life on Earth over the last five billion years. Like physics, biology has developed on two scales: the microscopically small and bigscale history. Molecular biology, discovering DNA, has decoded the "secret of life" (once ascribed to the Spirit of God). Evolutionary history has located the secret of life in natural selection operating over incremental variations across enormous time spans. As with physics, the two levels have been theoretically interrelated. The genetic level supplies variations do the coding of life and constructs molecular proteins. Organisms cope at their native-range levels, inhabiting ecosystems. Across deep evolutionary time, species are selected and transformed as they track changing environments. This process is not fine-tuned. To the contrary, evolutionary history can seem tinkering and makeshift. The genetic variations bubble up without regard to the needs of the organism, and the evolutionary selective forces select for survival without regard to advance. Many evolutionary theorists insist that nothing in natural selection theory guarantees progress. Here the cause of relating science to religion has been taken up adversely by some biologists, as with Richard Dawkins and his Blind Watchmaker. Stephen Jay Gould insists, "We are the accidental result of an unplanned process." Jacques Monod 
exclaims, "Chance alone is at the source of every innovation, of all creation in the biosphere." Outspokenly monotheist biologists are as rare as those who think physics, is compatible with monotheism are common. Typically, biologists seem to insist that if, from the perspective of science, they find what looks like contingency, then God is eliminated. But there are also biologists who emphasize the richness in biology: the fecund Earth, the vital creative processes continuing over time, the ascent of life from the simple to the complex, the production of more out of less over long millennia. Biologists can doubt creation, but none can doubt genesis. In fact, the earthly genesis is as impressive as anything in astronomy, because the life genesis requires a coding and a coping, factors wholly novel to anything previously encountered in physics or chemistry. Indeed, we can get from equally eminent scientists (though they are still not outspoken monotheists) a quite opposite reaction: the claim that, life is the destiny of these earthly chemicals. During the chemical evolution of life, when predecessors of DNA and RNA appear, bearing the possibility of genetic coding and information, they are conserved, writes Melvin Calvin, a biochemist, "not by accident but because of the peculiar chemistries of the various bases and amino acids. ... There is a kind of selectivity intrinsic in the structures." The evolution of life, so far from being random, is "a logical consequence "of natural principles. "This universe breeds life inevitably," concludes George Wald, an evolutionary biochemist. Michael Polanyi, a philosopher of science, finds that "there is a cumulative trend of changes tending towards higher levels of organization, among which the deepening of sentience and the rise of thought are the most conspicuous (Ferngren, 2017). From a seed of submicroscopic living particles - and from inanimate beginnings lying beyond these-we see emerging a race of sentient, responsible and creative beings. The spontaneous rise of such incomparably higher forms of being testifies directly to the operations of an orderly innovating principle. Also, it begins to become clear that the genes, once thought to operate blindly and at random, are a rather sophisticated problem solving device, conserving the successes of the past so as to search the nearby living space for novel innovations, without which life can neither survive nor develop. A kind of genetic engineering has been going on for several billion years, long before the biochemists began recently to undertake, this in their laboratories. Rather surprisingly, computer scientists, at the forefront of cognitive science, have discovered that analogues of genetic problem solving can be effectively used in advanced computing. Meanwhile, looking backward, we discover a primitive planetary'; environment in which the formation of living things had a high probability, that is, a pregnant, Earth. And looking forward to the next century, it is difficult to imagine that our evolutionary natural history will come to seem any less startlingly fecund and prolific. The dialogue between biology and religion will increasingly try to figure out whether in the genesis of these riches we need interference by a supernatural agency or the recognition of a marvelous endowment of matter with a propensity toward life. Do we need something to superintend the possibilities? There will not be much doubt that there has been a marvelous natural history, but there will be dialogue, debate, conflict over whether and how the story needs an Author. My prediction is that the watchmaker-design approach to the Creator, though it may remain appropriate in physics, will not prove the appropriate model for biology, where more autonomy and self-creativity must be combined with the divine will for life, a divine parenting entwined with spontaneous creative process (Harrison, 2015).

\section{LITERATURE REVIEW}

To recognize this relationship is to recognize that knowledge, or the lack of it, has an ethical component as well. The ethical feature is evident in the famous quote by W.K. Clifford, a significant figure of enlightened modernity, "it is wrong always, everywhere, and for anyone, to believe anything upon insufficient evidence. "He refers to this as 'the ethics of belief.' One's beliefs must be grounded in sound reasons, they must be rationally justified. Choices must be grounded in knowledge and not opinion. Modernity requires rational evidence as a necessary condition for belief as expressed above by naturalists, Hawking, Dawkins, and the others. The significance of these points is that there is a necessary relationship between belief, knowledge, and practice. But is all of this emphasis on reason anything more than the on-going misguided promotion of the Enlightenment dream? Some have argued that it is not, and that reason has been overstated and over extended. Postmodernity has proposed a more 'chastened' view of reason, one that limits reason's capability, which will be discussed in more detail in chapter four. Despite the postmodern challenge, naturalism has held fast to Enlightenment ideals and the deliverables of reason and has been the privileged position for most of the twentieth century and into the twenty-first. It has claimed to be the most reasonable position. Part of the explanation for its 
success has been due to the failure of theism to produce rational justification for its truth claims, thus the declaration that religion is based on a blind faith and not reason. To avoid this same fate, naturalism will eventually face the same critical tribunal. For it to succeed and continue as the privileged view, naturalism will have to demonstrate that it is indeed based on a rationally justified, sound argument. It must produce reasons that prove its first principles. That is, it must be shown to be based on more than dogma, opinion, and tradition (Cantor, 2016). This notion regarding the significance of reason raises an important question; if naturalism is based on facts and is the most rational view, then why would any rational person opt for an alternative view? The obvious response by many naturalists is that a rational person would not. Hence the charge that religion is non-cognitive, and believers have no rational basis for their belief seems to substantiate the need for a category distinction. Given the very real tension here, how, then, is this issue to be explained? What is apparent is that in the commonly accepted paradigm there are two distinct categories of belief systems. One category consists of a naturalistic view of the world and the other category consists of a multitude of alternative belief systems that are unified in their rejection of naturalism. While the idea of naturalism is reasonably clear as explained above, of what, then, does the category called religion consist? What is religion and, more specifically, what is a religious belief and a religious belief system? Is religion a thing, an intrinsic part of human nature (sui generis) that all humans innately possess? That is, do they have a religious inclination by nature? Is it something that is identifiable that can be researched and studied as a science and as a cultural phenomenon? Does it require a discipline that can justify inquiry and a 'science of religion' or 'phenomenology of religion'?20 Is it something that can be isolated and scientifically analyzed as many scholars in the field of religious studies, past and present, have said that it is? Or is it as other scholars have argued-just an ideological social or psychological construct and not an isolatable thing in itself to be studied? Some contemporary scholars have attempted to answer these questions by exposing the idea of religion as a modern Western invention, an ideology, and created, whether consciously or unconsciously, for the purpose of legitimating authority and power within institutions (Blavatsky, 2018).

\section{What is science, and what is religion?}

In order to understand the scope of science and religion and what interactions there are between them, we must at least get a rough sense of what science and religion are. After all, "science" and "religion" are not eternally unchanging terms with unambiguous meanings. Indeed, they are terms that were coined recently, with meanings that vary across times and cultures. Before the nineteenth century, the term "religion" was rarely used. For medieval authors, such as Aquinas, the term religio meant piety or worship, and was denied of "religious" systems outside of what he considered orthodoxy (Fraser, 2016). The term "science" as it is currently used also became common only in the nineteenth century. Prior to this, what we call "science" was referred to as "natural philosophy" or "experimental philosophy". William Whewell (1834) standardized the term "scientist" to refer to practitioners of diverse natural philosophies. Philosophers of science have attempted to demarcate science from other knowledge-seeking endeavors, in particular religion. For instance, Karl Popper (1959) claimed that scientific hypotheses (unlike religious ones) are in principle falsifiable. Many (e.g., Taylor 1996) affirm a difference between science and religion, even if the meanings of both terms are historically contingent. They disagree, however, on how to precisely (and across times and cultures) demarcate the two domains (Lessl, 2018).

One way to distinguish between science and religion is the claim that science concerns the natural world, whereas religion concerns both the natural and the supernatural. Scientific explanations do not appeal to supernatural entities such as gods or angels (fallen or not), or to non-natural forces (like miracles, karma, or Qi). For example, neuroscientists typically explain our thoughts in terms of brain states, not by reference to an immaterial soul or spirit (Fergusson, 2016).

Naturalists draw a distinction between methodological naturalism, an epistemological principle that limits scientific inquiry to natural entities and laws, and ontological or philosophical naturalism, a metaphysical principle that rejects the supernatural. Since methodological naturalism is concerned with the practice of science (with the kinds of entities and processes that are invoked), it does not make any statements about whether or not supernatural entities exist. They might exist but lie outside of the scope of scientific investigation. Some authors hold that taking the results of science seriously entails negative answers to such persistent questions as free will or moral knowledge. However, these stronger conclusions are controversial (Scheitle, \& Ecklund, 2017). 
The view that science can be demarcated from religion in its methodological naturalism is more commonly accepted. For instance, in the Kitzmiller versus Dover trial, the philosopher of science Robert Pennock was called to testify by the plaintiffs on whether Intelligent Design was a form of creationism, and therefore religion. If it were, the Dover school board policy would violate the Establishment Clause of the First Amendment to the United States

Constitution. Building on earlier work, Pennock argued that Intelligent Design, in its appeal to supernatural mechanisms, was not methodologically naturalistic, and that methodological naturalism is an essential component of science - though it is not a dogmatic requirement, it flows from reasonable evidential requirements, such as the ability to test theories empirically (Stone, 2016).

Natural philosophers, such as Isaac Newton, Johannes Kepler, Robert Hooke, and Robert Boyle, sometimes appealed to supernatural agents in their natural philosophy (which we now call "science"). Still, overall there was a tendency to favor naturalistic explanations in natural philosophy. This preference for naturalistic causes may have been encouraged by past successes of naturalistic explanations, leading authors such as Paul Draper (2005) to argue that the success of methodological naturalism could be evidence for ontological naturalism. Explicit methodological naturalism arose in the nineteenth century with the X-club, a lobby group for the professionalization of science founded in 1864 by Thomas Huxley and friends, which aimed to promote a science that would be free from religious dogmas. The $\mathrm{X}$-club may have been in part motivated by the desire to remove competition by amateurclergymen scientists in the field of science, and thus to open up the field to fulltime professionals (Barrett, 2018). Because "science" and "religion" defy definition, discussing the relationship between science (in general) and religion (in general) may be meaningless. For example, Kelly Clark (2014) argues that we can only sensibly inquire into the relationship between a widely accepted claim of science (such as quantum mechanics or findings in neuroscience) and a specific claim of a particular religion (such as Islamic understandings of divine providence or Buddhist views of the no-self) (Kaden, et al.2018).

\section{The Idea of Religion}

After using the term religion numerous times above and discussing the tension surrounding it, it is significant to note again that today the term, religion, is considered undefinable by many religion scholars and has led to much confusion as to what religion is and just as important, what it is not. But is it necessary to define the term? Anthropologist, Talal Asad, has commented that "there cannot be a universal definition of religion, not only because its constituent elements and relationships are historically specific, but because that definition is itself the historic product of discursive processes."In other words, any attempt at definition would need to be contextualized. As Brooke also noted above, the historical context is significant for understanding the idea of religion. What is meant by these scholars is that the term cannot be universalized. But the attempt continues. Arguably, additional confusion has been largely due to the efforts of religion theorists to negotiate in and around the dichotomy in question. To persist in using the term without an understanding of what it is, is to perpetuate the confusion. Some kind of workable definition seems imperative. A term that cannot be accurately defined presents its own set of problems, one being that it cannot be a concept (Shane, et al. 2016). A concept allows for differentiation from what it is not by getting to the term's essential meaning. The essence of something is identified by isolating the distinctive qualities that all members of a class and only members of that class always have. At present, the term religion does not allow this. As a result, many texts on the subject address, albeit reluctantly, a series of questions such as the following, but without a clear resolution. How are religions identified and what are their essential components? Do some beliefs and practices constitute a religion while others do not? Are all humans religious or are only some religious? How does a religious understanding of the world differ from a non-religious one? What is religious knowledge and what is religious belief? Within the context of the current understanding, these analytical types of questions can be answered with only a relative degree of accuracy, if at all. Without a workable, sustainable definition that allows for at least a minimal consensus on the fundamentals makes a distinctive objective for religious studies virtually impossible. For instance, how do religious studies differ from cultural studies, anthropological studies, philosophical studies, political studies, theological studies, or scientific studies for that matter? Granted, there may be overlap and shared terms in all of these, but what is the essential difference between these disciplines and so-called religion? Some would argue that there is no difference and that so-called religions are nothing more than socially constructed ideologies that need to be researched as cultural phenomena, which will be discussed in more detail below. Religion scholars have struggled with this most challenging 
demand for definition and its place in intellectual inquiry. For religion to be a concept it must have specific characteristics that all members and only members of the class 'religion' have in common. And as just mentioned, this allows the idea of religion to be differentiated from what it is not. It is at this point that comprehensive definitions have stumbled. Consequently, many religion scholars accept as incontestable that the term, religion, is undefinable, considering it simply a collective name, and opt for something like William James' view that religion "consists in the belief that there is an unseen order, and that our supreme good lies in harmoniously adjusting ourselves thereto."48 But this statement is exceedingly broad, contributing to and illustrating the problem. The difficulty here is that this expression is so broad that it could conceivably include all views, including naturalism. A naturalist may propose that "our supreme good lies in harmoniously adjusting ourselves" to the "unseen order" inherent in natural selection and the survival of the fittest. But if that is the intention of the statement, then the dichotomy would lose its meaning and dissolve. All views could be included in only one category, the religion category, or the non-religion category. If all is religion, then none is religion. But this, most likely, was not James' intention at all. However, an assertion like this when not clearly crafted loses its intended meaning. Though it does indicate the difficulty in identifying a common characteristic that allows for a comprehensive definition for all that is typically called religion. But perhaps, it is not as difficult as it may at first appear (Sørensen, 2017).

\section{Contextual Factors and Individual Differences}

The ways in which people use natural and supernatural explanations are quite flexible and context sensitive. Legare et al. [in press] suggested that people engage in all three kinds of coexistence thinking (i.e., target dependent, synthetic, and integrated) depending on the context: contextual information, cultural input, and the difficulty of reconciling both kinds of explanations influence the interpretive frame of a particular event and subsequent attempts to achieve explanatory coherence. Moreover, they argued that access to multiple explanatory frameworks is a universal psychological experience and resolving conflicts between multiple explanatory systems is a general cognitive challenge. Their claim is that age and experience coupled with language and contextual influences operate at a relatively global level to influence the normative reasoning patterns within particular groups or cultures. (Nicholson, 2016), also speculated about why an individual might engage in one or the other of the previous three kinds of coexistence thinking. One possibility is that some kinds of coexistence thinking may require more cognitive effort to reconcile views that seem to be in direct competition or even incompatible. For both children and adults, they suggested that perceived conflicts or tensions between explanatory systems might trigger the effort to create a more coherent and integrated belief system. But even in these cases, the kinds of explanations used are clearly dependent upon what an individual is exposed to in his or her family of origin and broader culture. The psychological data do not support the claim that, when available, natural or scientific explanations replace supernatural or religious ones. Instead, (Catto, et al. 2019), concluded that increases in knowledge, education, and technology do not inevitably lead to the replacement of supernatural explanatory systems. They concluded that (a) instead of abandoning supernatural explanations in situations of conflict with scientific or natural explanations, people find ways to accommodate supernatural explanations by sometimes integrating and sometimes separating them from natural explanations, and that (b) supernatural reasoning seems to be a general feature of human cognition. There are numerous questions and issues of a theoretical or conceptual nature that one could address concerning the studies just described. First, one of the implications of these studies is that people combine natural and supernatural explanations in a number of intriguing ways. This raises the more general question of how explanations of different kinds are related to one another. To address this, we introduce (briefly) some distinctions that make a more detailed classification of explanations possible. The second issue we will address is the question of how the psychological data about different types of reasoning relate to philosophical categories of possible relationships between religion and science. We examine this issue by discussing several different philosophical models on this topic, which distinguish different types of explanatory coexistence. In the next section, we will focus on the former issue and subsequent sections are reserved for the latter (Morrison, 2016).

\section{Relation between religion and science}

Since the 1960s, scholars in theology, philosophy, history, and the sciences have studied the relationship between science and religion. Science and religion is a recognized field of study with dedicated journals (e.g., Zygon: Journal of Religion and Science), academic chairs (e.g., the Andreas Idreos Professor of Science and Religion at Oxford University), scholarly societies (e.g., the Science and 
Religion Forum), and recurring conferences (e.g., the European Society for the Study of Science and Theology holds meetings every two years). Most of its authors are either theologians (e.g., John Haught, Sarah Coakley), philosophers with an interest in science (e.g., Nancey Murphy), or (former) scientists with long-standing interests in religion, some of whom are also ordained clergy (e.g., the physicist John Polkinghorne, the biochemist Arthur Peacocke, and the molecular biophysicist Alister McGrath) (Moon, et al. 2019).

The systematic study of science and religion started in the 1960s, with authors such as Ian Barbour (1966) and Thomas F. Torrance (1969) who challenged the prevailing view that science and religion were either at war or indifferent to each other. Barbour's Issues in Science and Religion (1966) set out several enduring themes of the field, including a comparison of methodology and theory in both fields. Zygon, the first specialist journal on science and religion, was also founded in 1966 . While the early study of science and religion focused on methodological issues, authors from the late $1980 \mathrm{~s}$ to the 2000s developed contextual approaches, including detailed historical examinations of the relationship between science and religion (e.g., Brooke 1991). Peter Harrison (1998) challenged the warfare model by arguing that Protestant theological conceptions of nature and humanity helped to give rise to science in the seventeenth century. Peter Bowler (2001, 2009) drew attention to a broad movement of liberal Christians and evolutionists in the nineteenth and twentieth centuries who aimed to reconcile evolutionary theory with religious belief (Avon \& Pelletier, 2016).

In the 1990s, the Vatican Observatory (Castel Gandolfo, Italy) and the Center for Theology and the Natural Sciences (Berkeley, California) co-sponsored a series of conferences on divine action. It had contributors from philosophy and theology (e.g., Nancey Murphy) and the sciences (e.g., Francisco Ayala). The aim of these conferences was to understand divine action in the light of contemporary sciences. Each of the five conferences, and each edited volume that arose from it, was devoted to an area of natural science and its interaction with religion, including quantum cosmology, chaos and complexity, evolutionary and molecular biology (Lanman, 2019).

In the contemporary public sphere, the most prominent interaction between science and religion concerns evolutionary theory and creationism/Intelligent Design. The legal battles (e.g., the Kitzmiller versus Dover trial in 2005) and lobbying surrounding the teaching of evolution and creationism in American schools suggest that religion and science conflict. However, even if one were to focus on the reception of evolutionary theory, the relationship between religion and science is complex. For instance, in the United Kingdom, scientists, clergy, and popular writers, sought to reconcile science and religion during the nineteenth and early twentieth century, whereas the United States saw the rise of a fundamentalist opposition to evolutionary thinking, exemplified by the Scopes trial in 1925 (Corrigan, 2017).

In recent decades, Church leaders have issued conciliatory public statements on evolutionary theory. Pope John Paul II (1996) affirmed evolutionary theory in his message to the Pontifical Academy of Sciences, but rejected it for the human soul, which he saw as the result of a separate, special creation. The Church of England publicly endorsed evolutionary theory (e.g., M. Brown 2008), including an apology to Charles Darwin for its initial rejection of his theory (Streib \& Klein, 2016).

For the past fifty years, science and religion has been de facto Western science and Christianity - to what extent can Christian beliefs be brought in line with the results of Western science? The field of science and religion has only recently turned to an examination of non-Christian traditions, such as Judaism, Hinduism, Buddhism, and Islam, providing a richer picture of interaction (Balslev, 2015).

Several typologies characterize the interaction between science and religion. For example, Mikael Stenmark (2004) distinguishes between three views: the independence view (no overlap between science and religion), the contact view (some overlap between the fields), and a union of the domains of science and religion; within those views he recognizes further subdivisions, e.g., the contact can be in the form of conflict or harmony. The most influential model of the relationships between science and religion remains Barbour's (2000): conflict, independence, dialogue, and integration. Subsequent authors, as well as Barbour himself, have refined and amended this taxonomy. However, others (e.g., Cantor and Kenny 2001) have argued that it is not useful to understand past interactions between both fields. For one thing, it focuses on the cognitive content of religions at the expense of other aspects, such as rituals and social structures. Moreover, there is no clear definition of what conflict means (evidential or logical). The model is not as philosophically sophisticated as some of its successors, such as (Bentley, 2018).

The conflict model, which holds that science and religion are in perpetual and principal conflict, relies heavily on two 
historical narratives: the trial of Galileo (see Dawes 2016 for a contemporary re-examination) and the reception of Darwinism (see Bowler 2001). The conflict model was developed and defended in the nineteenth century by the following two publications: John Draper's (1874) History of the Conflict between

Religion and Science and White's (1896) two-volume opus A History of the Warfare of Science with Theology in Christendom. Both authors argued that science and religion inevitably conflict as they essentially discuss the same domain. The vast majority of authors in the science and religion field is critical of the conflict model and believes it is based on a shallow and partisan reading of the historical record. Ironically, two views that otherwise have little in common, scientific materialism and extreme biblical literalism, both assume a conflict model: both assume that if science is right, religion is wrong, or vice versa (Avon \& Pelletier, 2016).

While the conflict model is at present a minority position, some have used philosophical argumentation (e.g., Philipse 2012) or have carefully re-examined historical evidence such as the Galileo trial (e.g., Dawes 2016) to argue for this model. Alvin Plantinga (2011) has argued that the conflict is not between science and religion, but between science and naturalism (Balslev, 2015).

The independence model holds that science and religion explore separate domains that ask distinct questions. Stephen Jay Gould developed an influential independence model with his NOMA principle ("Non-

Overlapping Magisteria"):

The lack of conflict between science and religion arises from a lack of overlap between their respective domains of professional expertise (Bentley, 2018). He identified science's areas of expertise as empirical questions about the constitution of the universe, and religion's domains of expertise as ethical values and spiritual meaning. NOMA is both descriptive and normative: religious leaders should refrain from making factual claims about, for instance, evolutionary theory, just as scientists should not claim insight on moral matters. Gould held that there might be interactions at the borders of each magisterium, such as our responsibility toward other creatures. One obvious problem with the independence model is that if religion were barred from making any statement of fact it would be difficult to justify the claims of value and ethics, e.g., one could not argue that one should love one's neighbor because it pleases the creator (Worrall 2004). Moreover, religions do seem to make empirical claims, for example, that Jesus appeared after his death or that the early Hebrews passed through the parted waters of the Red Sea (Corrigan, 2017).

The dialogue model proposes a mutualistic relationship between religion and science. Unlike independence, dialogue assumes that there is common ground between both fields, perhaps in their presuppositions, methods, and concepts. For example, the Christian doctrine of creation may have encouraged science by assuming that creation (being the product of a designer) is both intelligible and orderly, so one can expect there are laws that can be discovered. Creation, as a product of God's free actions, is also contingent, so the laws of nature cannot be learned through a priori thinking, which prompts the need for empirical investigation. According to Barbour (2000), both scientific and theological inquiry are theory-dependent (or at least model-dependent, e.g., the doctrine of the Trinity colors how Christian theologians interpret the first chapters of Genesis), rely on metaphors and models, and value coherence, comprehensiveness, and fruitfulness. In dialogue, the fields remain separate, but they talk to each other, using common methods, concepts, and presuppositions. Wentzel van Huyssteen (1998) has argued for a dialogue position, proposing that science and religion can be in a graceful duet, based on their epistemological overlaps (Ferngren, 2017).

The integration model is more extensive in its unification of science and theology. Barbour (2000) identifies three forms of integration. The first is natural theology, which formulates arguments for the existence and attributes of God. It uses results of the natural sciences as premises in its arguments. For instance, the supposition that the universe has a temporal origin features in contemporary cosmological arguments for the existence of God, and the fact that the cosmological constants and laws of nature are lifepermitting (whereas many other combinations of constants and laws would not permit life) is used in contemporary finetuning arguments. The second, theology of nature, starts not from science but from a religious framework, and examines how this can enrich or even revise findings of the sciences. For example, McGrath (2016) developed a Christian theology of nature, examining how nature and scientific findings can be regarded through a Christian lens. Thirdly, Barbour believed that Whitehead's process philosophy was a promising way to integrate science and religion (Fraser, 2016).

While integration seems attractive (especially to theologians), it is difficult to do justice to both the science and religion aspects of a given domain, 
especially given their complexities. For example, Pierre Teilhard de Chardin (1971), who was both knowledgeable in paleoanthropology and theology, ended up with an unconventional view of evolution as teleological (which brought him into trouble with the scientific establishment), and with an unorthodox theology (with an unconventional interpretation of original sin that brought him into trouble with the Roman Catholic

Church). Theological heterodoxy, by itself, is no reason to doubt a model, but it points to difficulties for the integration model in becoming successful in the broader community of theologians and philosophers. Moreover, integration seems skewed towards theism as Barbour described arguments based on scientific results that support (but do not demonstrate) theism, but failed to discuss arguments based on scientific results that support (but do not demonstrate) the denial of theism (Harrison, 2015).

\section{DISCUSSION}

Discussing further the epistemological distinction between the scientist, who carries out his research in a cognitive realm of a conceited reason, and a scientist open to humble contemplation, we may observe the words of the great Capadocchian theologian: "The mind that unifies with the divine spirit can see and penetrate into such big and divine things that only the divine grace and its state may allow". Referring to the last aspects, we believe that the spiritualization of a scientist's rationality brought by the interpersonal dialogue with the Orthodox theologian and developed by his openness towards humble contemplation and faith is not equal to the "state of unity of the mind with divine grace" mentioned by Saint Basil the Great. The spiritualization of rationality by means of interpersonal dialogue is at most an "appetizer" of the state of unity as it is found lower on the spiritual ascent of abandoning sins and addictions. Even so, the acquiring of spiritualization of the scientist's rationality has its importance, as it is the first step towards making the scientific research less sinful through abandoning the arrogance of rationality and opening towards humble contemplation.

According to the patristic vision, "God created the world for a reason and for a specific purpose. He made it out of kindness, to share His love with other beings . . . The world as nature is created for human beings, as the rationality of the world with multiple dimensions acquires meaning only in man or comes to fruition only in man". Above all, "the world and its things unveil their meanings as their rationality is seen by man, as having personal God as the creative source, they are seen as God's means of love, the dialogue of God with men . . . The dialogue of God with man through things contributes to his development as these are images or transparent faces of God's rationalities, His meanings as he created them, the meanings leading man more towards the self and self-development. Man, therefore develops through things as through them man understands the loving intentions of God". In this sense, Saint Gregory Palama explains that "As God is neither seen, nor physical, He may be known but through sensitive and intelligible beings. As knowledge is that of beings and through beings God is shown". Saint Maxim the Confessor states that in the unseen things of God-that have been seen since the creation of the world and can be understood in His creatures-are shown the "reasons of things made before time by God ... These are unseen, they are understood through beings, as all beings of God contemplated by us through our nature by means of knowledge and these reveal to us in a hidden way the reasons of their creation and through them the purpose of God in every being". We have seen earlier in our study that only the natural reason of man cannot understand the total rationality of things. But it can know enough as to open man towards humble contemplation and faith, and starting from the things seen, man can understand the hidden and unseen reasons of things. It may happen only if the mind is given the grace of faith and the light of the Holy Spirit. It happens when reason is spiritualized. Similarly, one of the hesychast followers, Patriarch Calist, graciously contemplates on the existence in its wholeness, on the Creator and his work: "I see myself full of Holy Light from the heart by the grace of God as a lampad full of soul's light and if it can be said I am introduced into the reason of beings and I see all rationality united in a mysterious Reason and all from Scriptures ends in that Reason" (emphasis added). By spiritualization, the reason is lighted, expanded and may encompass the paradoxical logic of grace, the logic of faith as much as it is allowed to man. The soul repents, undertakes Metanoia, changes its thoughts; there is a shift of human rationality towards God, towards faith. Moreover, by believing, then reason understands the logic of faith, as Isaiah the Prophet said, "If you do not believe, you do not understand" and Saint Basil the Great makes it clear: "Good may be truly understood by reason only through faith". The main idea that may be drawn from our discussion is that in order to understand the mysterious reason of things, the natural reason of a scientist should also be structured by grace, it should be spiritualized based on the divine grace 
and then it can understand. For a scientist, to acquire the mysterious meanings of things through the eyes of a spiritualized reason means to experience a genuine epistemological transfiguration: the scientist who carries out his research through the eyes of spiritualized rationality may discover a reality he has never seen before through the eyes of his natural rationality; namely, he may discover the profound divine meaning of the investigated world. Basically, the scientist may obtain the state of epistemological transfiguration together with the theologian in his effort to understand the reality he studies. The scientist should rely both on demonstrable truth (acquired through observational, laboratory or mental experiments) and also on indemonstrable truth (acquired from divine Revelation). So, the scientific truth is not altered, weakened or relativized by its unification (unblended and undivided) with the revealed truth, but is consolidated and enriched acquiring a deepness that otherwise would not be accessible. Using this kind of knowledge, the scientist does not turn into a hermit or a theologian. He will still be a scientist carrying out research. Finally, trying to summarize what has been discussed about the specific features of the personalist dialogue between Orthodox theology and science, it is clear that the existence of the interpersonal communion by joint synergic work between a theologian and a scientist humbles the natural reason of the latter. The scientist's rationality opens towards faith and gets spiritualized. It becomes able to acquire the state of epistemological transfiguration needed to discover the divine rationality of the investigated reality. Experienced in such a way, scientific research becomes a confession of faith used for the personal redemption of the scientist.

\section{CONCLUSION}

Based on this review, we would like to draw several conclusions and provide some recommendations. First, the topic of rationality is important to consider when discussing the relationship between psychological and philosophical accounts of explanatory coexistence. Although a discussion about the rationality of the philosophical models reviewed is outside the scope of this article, we acknowledge that the relationship between normative assessment and psychological realities is complex. The data reviewed by Legare et al. [in press] strongly support the claim that explanatory coexistence is an empirically verifiable state of affairs; people hold supernatural and natural explanations for the same explanandum at the same time. Additionally, supernatural reasoning seems to be a stable feature of human cognition [McCauley, in press] and difficult to avoid or separate from natural and scientific reasoning. However, from this we cannot simply conclude that coexistence is rational or warranted. Various philosophical views are possible regardless of the psychological fact of explanatory coexistence. Second, we propose that one of the most characteristic features of religious explanations is that they are given in intentional terms. Contrary to scientific explanations that tend to conceptualize the explanandum and the explanans in terms identifiable by theories of natural sciences, religious explanations posit the intentional actions of supernatural agents as causes of events [for overviews, see Saunders, 2002; Ward, 2007]. Generally speaking, supernatural agent explanation is a subcategory of intentional explanation. The basic form of such explanations allows us to explain certain outcomes as the effects of agents' intentional (mental) states such as desires and beliefs. This pattern of explanation is at work in both supernatural and natural cases. Supernatural entities are conceptualized as agents that act on the basis of their knowledge and aims. Although intentional explanations have causal and intentional components, their exact relationship is difficult to spell out. Thus, whenever we consider intentional explanations, we are stuck between two intuitions: on the one hand, agents seem to initiate new causal chains in the natural world, but, on the other hand, we find it difficult to see how these causal chains are related to the mechanical workings of nature.

This has led some philosophers to make a strong distinction between personal (intentional) explanations that invoke intentional states as explanans and scientific explanations that invoke physical forces and regularities. Furthermore, some philosophers defend the independence of intentional explanations against scientific ones for different reasons; for example, Swinburne [2004] defended personal explanation as dualist whereas (Harrison, 2015), defended it as materialists and folk-psychological realists. Conversely, some strongly naturalist philosophers have argued that intentional explanations should either be amenable to reduction to scientific explanations or be eliminated completely. Although these concerns are distinctively philosophical, they nevertheless have consequences for how we conceptualize the relationship between supernatural and natural explanations. Our point here is not that psychological studies should produce or assume one particular solution to these philosophical problems.

Instead, we propose that when empirical research is conducted, philosophical questions loom in the background 
and should influence how the studies are designed and interpreted. It is useful to make these assumptions as transparent as possible. Finally, we suggest that psychological accounts of the coexistence of supernatural and natural explanations may be developed further by adopting some of the conceptual resources provided by philosophers of religion, and conversely, that philosophical accounts of religion and science can be informed by psychological data on how people reason about these topics. Overly reductionist interpretations of psychological results can be avoided by examining the philosophical work on the pragmatics of explanation in each of these domains. Philosophical accounts that focus on the utility of different kinds of explanations as answers to different kinds of questions suggest that further psychological research into the contextual factors that influence the implicit contrasts that people adopt in particular situations would be informative. We also suggest that more attention needs to be directed towards the role of intentionality in supernatural explanation. By contrasting supernatural explanations with physical explanations, one sets up only one particular kind of contrast; instead, it may be more useful to examine supernatural explanations for similarities with everyday folk psychological explanations. From a psychological perspective, we propose that the total conflict model, the independence model, and the constructivist version of the reconciliation model are not supported by the psychological data. On the one hand, the total conflict model forces its adherents to give up supernatural explanations altogether, which is incompatible with the widespread belief that supernatural explanations answer questions that natural explanations do not answer. On the other hand, the independence model assumes that supernatural explanations are not causal, but that supernatural explanations provide meaning and value. In contrast to this, we propose that many people understand supernatural explanations as genuinely causal explanations (even if they do not have access to the causal mechanisms involved). Finally, the constructivist reconciliation model goes against our intuitions about the existence of the physical world, making it difficult to conceptualize for most people. We propose that the conservative, traditional, and liberal reconciliation models best map onto the types of thinking identified in the psychological research. This suggests that philosophical and theological models along these lines would be perceived to be the most intuitively plausible from a psychological perspective.
Philosophical theories on the religion and science dialogue would also benefit from the psychological data on this topic; information about how people actually reason about the relationship between religious and scientific explanations can inform philosophical work in a number of ways [for an overview, see Lawson, 2005]. Psychological data can inform philosophical theory about what is plausible from the point of view of our everyday intuitions. For example, we propose that some philosophical models of the relationship between religion and science are unrepresentative of human cognition on this topic and thus unlikely to be widely distributed without considerable cultural scaffolding. By examining the mutually informative connections between philosophical and psychological accounts of the coexistence of natural and supernatural explanations, we hope to inspire interdisciplinary research on this topic. We propose that emerging psychological accounts of the coexistence of natural and supernatural explanations may be developed further by adopting the conceptual resources provided by philosophers, especially with respect to the topics of explanation and possible theoretical relationships between science and religion. Furthermore, psychological data can inform philosophical accounts by providing information concerning how people reason about this fundamental topic in human cognition.

\section{REFERENCES}

[1] Ferngren, G. B. (Ed.). (2017). Science and religion: a historical introduction. JHU Press.

[2] Harrison, P. (2015). The territories of science and religion. University of Chicago Press.

[3] Cantor, G. (2016). Michael Faraday: Sandemanian and scientist: a study of science and religion in the nineteenth century. Springer.

[4] Blavatsky, H. P. (2018). The Secret Doctrine: The Synthesis of Science, Religion, and Philosophy Volume II: Anthropogenesis (Vol. 2). Lulu. com.

[5] Fraser, S. (2016). Discovering and advancing school students' perceptions of the relationships between science and religion. Dialogue Australasia, 36, 30-33.

[6] Lessl, T. (2018). Naïve Empiricism and the Nature of Science in Narratives of Conflict Between Science and Religion. Science \& Education, 27(7-8), 625-636.

[7] Fergusson, D. (2016). David Wilkinson, Science, Religion and the Search for Extraterrestrial Intelligence (Oxford: OUP, 2013), pp. xii+ 228.£ 25.00. Scottish Journal of Theology, 69(3), 360-361.

[8] Scheitle, C. P., \& Ecklund, E. H. (2017). The influence of science popularizers on the public's view of religion and 
science: An experimental assessment. Public Understanding of Science, 26(1), 25-39.

[9] Stone, B. (2016). Religious Faith and Science in Contact. Journal of Religion \& Film, 2(2), 6.

[10] Barrett, J. L. (2018). Some common misunderstandings about cognitive approaches to the study of religion: a reply to Sterelny. Religion, Brain \& Behavior, 8(4), 425-428.

[11] Kaden, T., Jones, S., Catto, R., \& Elsdon-Baker, F. (2018). Knowledge as explanandum: disentangling lay and professional perspectives on science and religion. Studies in Religion/Sciences Religieuses, 47(4), 500-521.

[12] Shane, J. W., Binns, I. C., Meadows, L., Hermann, R. S., \& Benus, M. J. (2016). Beyond evolution: Addressing broad interactions between science and religion in science teacher education. Journal of Science Teacher Education, 27(2), 165-181.

[13] Sørensen, J. (2017). Western Esotericism and Cognitive Science of Religion. Aries, 17(1), 119-135.

[14] Nicholson, G. (2016). Science and Religion: Are They Complimentary or in Conflict?. International Journal of Sciences, 5(11), 14-22.

[15] Catto, R. A., Jones, S., Kaden, T., \& ElsdonBaker, F. (2019). Diversification and internationalization in the sociological study of science and religion. Sociology Compass, 13(8), e12721.

[16] Morrison, R. (2016). Religion and Science in the Eastern Mediterranean. Isis, 107(3), 579582.

[17] Moon, J. W., Krems, J. A., Cohen, A. B., \& Kenrick, D. T. (2019). Is nothing sacred? Religion, sex, and reproductive strategies. Current Directions in Psychological Science, 0963721419838242.

[18] Avon, D., \& Pelletier, D. (2016). Science and Religion in the 20th Century: An Introduction. Vingtième Siècle. Revue d'histoire, (2), 4-15.

[19] Lanman, J. A. (2019). On the nature and future of agency detection and religion. Religion, Brain \& Behavior, 9(3), 258-260.

[20] Corrigan, P. T. (2017). Religion and Ecology: Developing a Planetary Ethic by Whitney A. Bauman. The Goose, 16(1), 6.

[21] Streib, H., \& Klein, C. (2016). Religion and spirituality. In The Oxford Handbook of the Study of Religion.

[22] Balslev, A. N. (2015). "Science-Religion Samvada" and the Indian Cultural Heritage: with Nidhal Guessoum, "Islam and Science: The Next Phase of the Debates"; and Anindita Niyogi Balslev, “'Science-Religion Samvada'and the Indian Cultural Heritage”. Zygon®, 50(4), 877-892.

[23] Bentley, W. (2018). Is there a wall to peek over? Exploring approaches in the science and religion conversation. HTS Theological Studies, 74(1), 1-6. 